\title{
KEUNGGULAN BERSAING KOPERASI BERKAITAN DENGAN PENERAPAN INTELLECTUAL CAPITAL, MANAJEMEN KEANGGOTAAN DAN PARTISIPASI ANGGOTA
}

\author{
Dwi Gemina \\ Samsuri \\ Indra Cahya Kusuma \\ Fakultas Ekonomi Universitas Djuanda Bogor \\ Email: dwigemina@ymail.com
}

\begin{abstract}
Abstrak
Penelitian ini bertujuan untuk menentukan peranan Intellectual Capital, Manajemen Keanggotaan dan Partisipasi Anggota dalam keunggulan bersaing koperasi. Kuesioner didistribusikan kepada 208 responden. Metode Successive Interval digunakan untuk mengubah skala ordinal menjadi skala interval. Model penelitian ini ialah path analysis. Hasil penelitian ini menyatakan bahwa Intellectual Capital, Manajemen Keanggotaan dan Partisipasi Anggota secara bersama-sama maupun secara parsial berpengaruh terhadap keunggulan bersaing.
\end{abstract}

Kata kunci: Intellectual capital, manajemen keanggotaan, partisipasi anggota, keunggulan bersaing koperasi

\begin{abstract}
The objectives of this study were to determine intellectual capital application, membership management and member participation effects in Cooperative competitive advantage. Questionnaires were distributed to 208 respondents. The Successive Intervals method was used in order to convert ordinal scale of measurement to be interval measurement level. The Research model was a path analysis and the results of this study showed that the intellectual capital, membership management and member participation simultaneously and partially affected competitive advantage.
\end{abstract}

Keywords: Intellectual capital, membership management, member participation, cooperative competitive advantage

\section{PENDAHULUAN}

Perkembangan pasar global yang diwarnai dengan beberapa bentuk kesepakatan perdagangan baik di tingkat bilateral, regional maupun multilateral seperti Asean Free Area (AFTA), Asean Pasific Economic Cooperation (APEC), North American Free Trade Area (NAFTA), Europen Economic Cooperation (EEC), sehingga World Trade Organization (WTO). Banyak perubahan struktural sudah mempengaruhi ekonomi nasional, mengantisipasi iklim ekonomi yang lebih bebas pebisnis nasional perlu mempersiapkan kemampuan bersaing dengan cermat. Jika tidak persiapan secara terpadu, perubahan tata bisnis bersaing pada era globalisasi dan pasar bebas. Era menuntut perubahan menjadi produktif dan memandang perubahan sebagai sesuatu yang tidak dapat dihindari. Dengan berkurangnya peran proteksi dari pemerintah, perusahaan nasional baik Koperasi, BUMN dan BUMS diharapkan mampu menunjukkan kinerja yang tidak kalah dibanding perusahaan-perusahaan asing dan multinasional. Oleh karena itu perlu diciptakan iklim ekonomi nasional dari budaya kerja yang mendukung peningkatan kinerja. Ini berarti bahwa persaingan sehat layaknya ditumbuh kembangkan agar mau tidak mau menuntut pebisnis untuk meningkatkan kemampuan bersaingnya. Peran koperasi sangat penting dalam menumbuhkan dan mengembangkan potensi ekonomi rakyat serta dalam mewujudkan kehidupan demokrasi ekonomi yang mempunyai ciri-ciri demokratis, kebersamaan, kekeluargaan dan keterbukaan. Dalam kehidupan ekonomi seperti itu koperasi selayaknya memiliki ruang gerak dan kesempatan usaha yang luas, terutama yang menyangkut kepentingan ekonomi rakyat. Kemampuan pembangunan koperasi pada dasarnya sangat tergantung manajemen dan partisipasi anggota. Sesuai dengan sifat keanggotaannya yang ganda yaitu sebagai pemilik dan sekaligus sebagai pelanggan (pengguna jasa 
koperasi). Sebagai pemilik, anggota koperasi menentukan arah kebijaksanaan organisasi, termasuk pengurus, jenis kegiatan usaha dan sumber permodalan yang akan dikembangkan.

Tabel 1. Keragaan Koperasi Kota Bogor Tahun 2011

\begin{tabular}{clcc}
\hline No. & Keterangan & Satuan & Jumlah \\
\hline 1 & Jumlah Koperasi & Unit & 773 \\
2 & Jumlah Anggota & Orang & 46.938 \\
3 & Jumlah Modal Sendiri & Rp 000 & 54.240 .423 \\
4 & Jumlah Modal Luar & Rp 000 & 140.777 .542 \\
5 & Jumlah Volume Usaha & Rp 000 & 245.146 .695 \\
6 & Jumlah Asset & Rp 000 & 224.859 .367 \\
7 & Jumlah SHU & Rp 000 & 11.862 .993 \\
\hline
\end{tabular}

Sumber: Dinas Koperasi dan UKM Kota Bogor, 2012

Di sisi lain agar koperasi dapat menjadi media bagi peningkatan kegiatan ekonomi (dalam hal ini adalah anggota koperasi), maka koperasi sendiri harus berhasil dalam bidang manajemen. Oleh karena itulah era ini oleh Ulrich (1998) disebut sebagai era Intellectual Capital yang mana nilai asset suatu perusahaan tidak lagi ditentukan oleh seberapa besar nilai investasinya pada asset-asset wujud (tangible) semata, tetapi lebih kepada tak berwujud (intangle assets), sumber daya manusia (SDM) yang ada dalam organisasi yang bersangkutan (Ulrich, 1998). Komitmen yang tinggi diakui mampu membangkitkan kedekatan emosional karyawan (anggota dan pengurus koperasi) terhadap perusahaan koperasi, sehingga semangat juang yang terus dilakukan perbaikan yang telah menjadi suatu built-in dalam diri mereka (Caruana, 1997). Namun, komitmen saja tanpa didukung oleh kompetensi akan dapat berakibat fatal, karena koperasi hanya akan dipenuhi oleh orang-orang yang setia, loyal dan taat, tetapi tidak memiliki kemampuan yang memadai, sehingga kreativitas dan inovasi di dalam koperasi menjadi sesuatu yang langka. Sementara itu koperasi dengan banyak sumber daya manusia yang berbakat dan memiliki kompetensi yang tinggi, namun tanpa komitmen yang kuat, hanyalah sekumpulan orang hebat yang tidak dapat melakukan apapun. Bahwa dalam proses bisnis jasa seperti halnya dengan koperasi lebih didominasi oleh manusia, hubungan antar sistem di dalam organisasi merupakan prasyarat tercapainya organisasi yang efektif, secara langsung membutuhkan kemampuan pengelolaan sumber daya manusia yang lebih baik pula. Hasil studi Gilbert \& Parhizgari (2000) menunjukkan bahwa efektivitas pelayanan sangat dipengaruhi oleh proses dan hubungan antar proses yang ada di dalam perusahaan itu sendiri. Keunggulan bersaing inilah menurut Desatnick (1988) merupakan tuntutan yang sangat mendasar bagi siapapun saat ini, sehingga seluruh unsur di dalam organisasi perusahaan selalu dituntut untuk memiliki dan mengembangkan keunggulan kompetitifnya (Desatnick, 1988). Dua komponen yang diakui dan telah terbukti mampu menciptakan keunggulan kompetitif suatu perusahaan adalah intellectual capital, yang sangat ditentukan oleh seberapa tinggi komitmen dan kompetensi dari para karyawan (anggota dan pengurus koperasi) yang telibat. Kompetensi sebagai karaktersitik dasar terdiri dari kemampuan (skill), pengetahuan (knowledge) serta atribut personal (personal attributs) lainnya yang mampu membedakan seseorang yang perform dan tidak perform. Inti utama dari kompetensi sebagai alat penentu untuk memprediksikan keberhasilan kerja seseorang pada suatu posisi yang diaplikasikan rekrutmen, performance, appraisal, kompensasi dan training (Athur Andersen dalam Usmara, 2002). Dalam Undang-Undang Nomor 25 Tahun 1992 tentang Perkoperasian, ditegaskan pula tentang adanya pembinaan dalam bentuk bimbingan, kemudahaan dan perlindungan terhadap koperasi oleh pemerintah. Koperasi diberikan kesempatan usaha yang seluas-luasnya dan juga diupayakan terjalin tata hubungan usaha yang saling menguntungkan antara koperasi dengan badan usaha lainnya. Pengelolaan manajemen koperasi tidak terbatas pada pengelolaan usaha. Akan tetapi, juga harus memperhatikan fungsi keanggotaan dari koperasi itu sendiri. Fungsi operasional keanggotaan (pengadaan, pengembangan, manfaat, pemeliharaan dan pemutusan hubungan kerja) harus melalui fungsi manajemen (planning, organizing, actuating, controlling). Organisasi dan manajemen yang baik sangat erat kaitannya dengan efektivitas fungsi alat kelengkapan di dalam organisasi koperasi yakni: anggota, pengurus dan pengawas. Namun demikian koperasi dalam per-kembangannya seperti juga usaha negara dan swasta tidak terlepas dari tata ekonomi Indonesia yang dipengaruhi oleh perkembangan perubahan dan kecenderungan yang terjadi dalam sistem ekonomi dunia. Seperti yang dikemukakan oleh Davis (1999), lemahnya kemampuan bersaing koperasi, ditandai oleh pertumbuhan koperasi yang relatif rendah bahkan mengalami kemunduran. Untuk mencapai hal tersebut terlebih dahulu anggota dan pengurus harus memperhatikan pengelolaan manajemennya dengan baik sehingga dapat tercipta kesejahteraan dari anggota koperasi yang bersangkutan. Pengelolaan manajemen koperasi tidak terbatas pada pengelolaan usaha. Akan tetapi, juga harus memperhatikan fungsi keanggotaan dari koperasi itu sendiri. Kenyataan itu ditemui selama ini menunjukan bahwa kelemahan-kelemahan di bidang manajemen yang memberikan citra koperasi yang 
baik. Keikutsertaan dan keaktifan anggota koperasi masih terasa lemah dan malahan sebagian anggota ada yang tidak berpartisipasi. Oleh sebab itu, sangat penting untuk mengetahui intellectual capital dan manajemen keanggotaan serta partisipasi anggota terhadap kemampuan koperasi untuk memenangkan persaingan dalam mengelola koperasi.

\section{LANDASAN TEORI DAN HIPOTESIS}

Koperasi sebagai sebuah organisasi yang beranggotakan sekumpulan manusia untuk menjalankan aktivitas ekonomi dan sosial bagi memberi faedah kepada anggota-anggotanya. Ciri yang paling penting dalam penumbuhan koperasi ialah adanya tujuan bersama yang ingin dicapai (common needs) di kalangan orang-orang yang menumbuhkan koperasi tersebut. Menurut Hanel (1989) menyatakan bahwa karakteristik dasar dari organisasi koperasi adalah: 1) Kesukarelaan untuk bekerja sama, hal ini dapat berarti tidak ada keanggotaan yang bersifat keharusan secara tidak langsung atau secara bersyarat; 2) Kesamaan hak dan kerjasama; 3) Kebebasan yang cukup untuk mewujudkan kepentingan-kepentingan individu. Koperasi berbeda dengan organisasi bisnis lainnya, koperasi dimiliki oleh anggota dan juga para pemakai. Fakta ini membedakan koperasi dengan perusahaan lain yang para pemiliknya adalah investor. Badan usaha seperti koperasi merupakan badan usaha yang tidak berorientasi pada keuntungan (profit) semata. Selanjutnya menurut Ropke (2012) peran koperasi sangat penting dalam menumbuhkan dan mengembangkan potensi ekonomi masyarakat serta dalam mewujudkan kehidupan demokrasi ekonomi yang mempunyai ciri-ciri demokratis, kebersamaan, kekeluargaan, dan keterbukaan. Menyadari akan pentingnya koperasi maka pertumbuhan dan perkembangannya mutlak perlu ditingkatkan. Namun kemampuan koperasi untuk bergerak sejajar dengan badan usaha lainnya masih perlu ditingkatkan. Berbagai usaha dan terobosan untuk meningkatkan keunggulan sektor koperasi telah dan sedang dilakukan baik oleh gerakan koperasi maupun pemerintah yang selalu mengadakan perintisan dan pembinaan dengan berbagai tahapan dari tahap offisialisasi, tahap deoffisialisasi, hingga tahap mandiri (otonomi).

\section{Konsep Intellectual Capital}

Menurut Stewart (1994) bahwa intellectual capital dibagi dalam tiga bagian yaitu modal manusia (human capital), modal struktural (structural capital) dan modal pelanggan (relational capital). Modal manusia penting karena merupakan sumber inovasi dan pembaharuan. Di samping itu, intellectual capital menurut Ulrich (1998) adalah komitmen dan kom- petensi. Michael Haris dalam Suryana (2003) intellectual capital sama dengan competency kali comitment artinya meskipun ia memiliki tingkat pengetahuan yang tinggi apabila tidak disertai dengan komitmen yang tinggi maka wirausaha tersebut tidak akan dapat menggunakan modal intelektualnya.

\section{Manajemen Keanggotaan}

Menurut Swastha (1999), manajemen mempunyai fungsi-fungsi yaitu perencanaan, pengorganisasian, pengarahan, pengkoordinasian, dan pengawasan. Dari fungsi manajemen keanggotaan seperti manajemen sumber daya manusia menurut Kasmir (2008) dan Salim (1996) dapat diuraikan sebagai berikut: 1) Pengadaan adalah suatu usaha untuk mengadakan anggota yang sesuai dengan kebutuhan, baik jumlah, kualitas maupun jenis usahanya. Kegiatan ini meliputi proses perekrutan, seleksi dan penempatan anggota; 2) Pengembangan, suatu kegiatan dalam rangka meningkatkan mutu usaha anggota agar selalu dapat mengikuti perkembangan perusahaan maupun meningkatkan kemampuan usaha anggota, misalnya dalam bentuk pelatihan dan pengembangan; 3) Manfaat, fungsi ini merumuskan dan melaksanakan pemberian balas jasa yang layak bagi anggota dan menyesuaikan programprogram kerja dalam pencapaian tujuan koperasi; 4) Pemeliharaan, kegiatan ini merupakan suatu fungsi untuk mempertahankan dan meningkatkan kesejahteraan para anggotanya; 5) Pemutusan hubungan keanggotaan, kegiatan ini merupakan suatu fungsi untuk melaksanakan pemutusan hubungan keanggotaan sesuai dengan peraturan yang berlaku. Tujuan manajemen keanggotaan koperasi merupakan suatu cara koperasi untuk mendapat anggota secara terusmenerus meskipun pada perinsipnya koperasi memungkinkan untuk menghentikan keanggotaannya sewaktu-waktu secara bebas, yang disebabkan adanya manfaat yang diperoleh anggota dari koperasi lebih kecil dari manfaat yang diperoleh dari koperasi. Selanjutnya menurut Salim (1996) hal-hal yang perlu diperhatikan dalam manajemen keanggotaan koperasi sebagai berikut: 1) Organisasi koperasi tidak sembarang menerima anggota, harus melalui proses rekruitmen dari tujuan perusahaan koperasi, kegiatan perusahaan koperasi, jumlah anggota yang diterima dihubungkan dengan usaha yang dilakukan, kualitas dari pada anggota (umur, usaha, dapat melakukan tindakan hukum mempunyai keahlian tertentu), sehingga dapat diketahui anggota yang akan diterima, sehingga tidak merugikan kepentingan koperasi dan anggota lainnya; 2) Anggota harus dikembangkan jadi koperasi harus melatih dan mendidik para anggota; 3) Pemberian manfaat para perusahaan 
koperasi melalui pelayanan-pelayanan pada para anggota; 4) Kesejahteraan para anggota. tidak hanya ditentukan oleh pemenuhan kepentingan ekonomi tetapi juga bukan ekonomi seperti kebutuhan kesehatan, keamanan, sarana ibadah, sarana keluarga, sarana olah raga, rekreasi dan lain-lain; 5) Pengurus harus mengusahakan di dalam pengelolaan keanggotaan agar para anggota di dalam melakukan aktivitas untuk kepentingan usaha koperasi merasa yakin bahwa apabila tujuan dari perusahaan koperasi adalah untuk memenuhi kebutuhan para anggota dengan sendirinya dapat dipenuhi; 6) Masalah pemberhentian anggota organisasi koperasi harus berusaha agar seseorang yang masuk jadi anggota koperasi agar dijaga terus-menerus agar mempertahankan keanggotaannya sampai anggota itu meningkat kesejahtreraanya. Berdasarkan uraian di atas bahwa peranan manajemen keanggotaan sangat diperlukan oleh suatu organisasi atau perusahaan untuk mencapai tujuannya.

\section{Partisipasi Anggota dalam Koperasi}

Partisipasi anggota merupakan salah satu wujud serta anggota dalam koperasi. Partisipasi mengandung potensi yang luar biasa untuk membina kerja sebuah kelompok atau organisasi. Pada pasal 20 UndangUndang Nomor 25 Tahun 1992 dan penjelasannya disebutkan setiap anggota mempunyai kewajiban berpartisipasi dalam kegiatan usaha yang diselenggarakan oleh koperasi. Menurut Wirasasmita (1992) perkembangan koperasi sangat ditentukan oleh partisipasi anggotanya dalam hal: Melaksanakan tugasnya sebagai pemilik yaitu secara terus menerus membiayai perusahaan koperasi dan menggunakan haknya dalam rapat-rapat anggota. Melaksanakan tugasnya sebagai pelanggan yaitu secara terus menerus memanfaatkan fasilitas yang disediakan oleh perusahaan koperasi. Anggota koperasi seharusnya mendapat manfaat khusus dari koperasi karena sebagai pelanggan sekaligus pemilik, maka anggota koperasi akan mendapatkan promosi khusus. Masalah partisipasi ditentukan oleh kemampuan koperasi untuk dapat memberikan manfaat khusus yang mungkin tidak dapat diperoleh dari lembaga bukan koperasi. Kemanfaatan yang diperoleh dari koperasi harus senantiasa lebih besar daripada manfaat yang diperoleh dari perusahaan bukan koperasi. Hanel (1985) membedakan dimensi partisipasi anggota menjadi dua bagian yaitu: 1) Partisipasi kontributif yaitu partisipasi anggota sebagai pemilik. Partisipasi anggota dapat berupa penyertaan modal, pembentukan cadangan, pinjaman, mengambil bagian dalam penetapan tujuan, pembuatan keputusan dan pengawasan terhadap jalannya kehidupan koperasi; 2)
Partisipasi insentif yaitu partisipasi anggota sebagai pelanggan, yang mana para anggota memanfaatkan berbagai pelayanan yang disediakan koperasi untuk menunjang berbagai kepentingannya. Menurut Ropke (1989) tipe partisipasi anggota terdiri dari: a) partisipasi anggota dalam kontribusi atau memobilisasi sumber daya (resource); b) partisipasi dalam pengambilan keputusan yaitu perencanaan pelaksanaan dan pengawasan (decision making); c) partisipasi dalam usaha atau pemanfaatan pelayanan (benefits). Ada keuntungan (advantage) dalam meningkatkan partisipasi anggotanya yaitu: 1) adanya kebebasan untuk masuk atau keluar menjadi anggota; 2) demokrasi kepengurusan. Dari kedua prinsip ini akan memberikan keleluasan pada anggota untuk mengemukakan ide (voice) untuk bersuara (vote) dan juga memberikan keleluasan bagi mengecilnya partisipasi anggota, karena anggota dapat keluar atau mengundurkan diri dari partisipasi (exit), sehingga dapat menekan pengurus, akibat program, keputusan manajemen akan terpaksa sama dengan kebutuhan anggota melalui suara (voice), keluar (exit), ancaman (threat).

\section{Keunggulan Bersaing}

Menurut Porter (1999) untuk menganalisis karakteristik persaingan yang dihadapi antara lain: 1) Jumlah perusahaan dalam industri, bila hanya ada satu perusahaan dalam industri, maka secara teoris perusahaan yang bersangkutan bebas menetapkan harganya seberapa pun. Akan tetapi, sebaliknya bila industri terdiri dari banyak perusahaan, maka persaingan harga terjadi bila produk yang dihasilkan tidak terdiferensiasi. Hanya pemimpin industri yang leluasa menentukan perubahan harga; 2) Ukuran relatif setiap anggota dalam industri, bila perusahaan mempunyai pangsa pasar yang besar, maka perusahaan yang bersangkutan dapat memegang inisiatif perubahaan harga. Bila pangsa pasarnya kecil, maka harga menjadi pengikut; 3) Diferensiasi produk, bila perusahaan berpeluang melakukan diferensiasi dalam industrinya, maka perusahaan tersebut dapat mengendalikan penetapan harganya bahkan sekali pun perusahaan-perusahaan kecil dan banyak pesaing dalam industri; 4) Kemudahan untuk memasuki industri yang bersangkutan, bila suatu industri mudah untuk memasuki, maka perusahaan yang ada sulit mempengaruhi atau mengendalikan harga. Bila ada hambatan masuk pasar (barier to market entry), maka perusahaan yang sudah ada dalam industri tersebut dapat mengendalikan harga. Lebih lanjut menurut Porter (2011), untuk mencapai keunggulan bersaing terutama di pasar bebas, maka berbagai macam usaha 
ditempuh oleh perusahaan-perusahaan. Salah satu strategi yang terkenal digunakan dewasa ini strategi kompetitif (competitive strategy). Strategi kompetitif dapat dibedakan dalam banyak cara termasuk tingkat yang mana perusahaan mesti menekankan pada tiga hal utama yaitu: 'innovation', 'quality improvement', dan 'cost reduction'. Selanjutnya hubungan kompetensi dan komitmen yang dikenal dengan intellectual capital dan fungsi manajemen keanggotaan serta partisipasi anggota terhadap keunggulan bersaing pada koperasi dapat disusun dalam suatu paradigma penelitian seperti pada Gambar 1.

Berdasarkan kerangka pemikiran yang telah dijelaskan di atas, maka dihipotesiskan sebagai berikut: a) Penerapan intellectual capital mempunyai pengaruh terhadap keunggulan bersaing; b) Fungsifungsi manajemen keanggotaan pengadaan, pengembangan, manfaat, pemeliharaan, pemutusan hubungan kerja mempunyai pengaruh terhadap keunggulan bersaing; c) Aktif partisipasi anggota mempunyai pengaruh terhadap keunggulan bersaing; d) Semakin tepat penerapan intellectual capital dan pelaksanaan manajemen keanggotaan serta semakin aktif partisipasi anggota terhadap keunggulan bersaing. Hipotesis tersebut diuji melalui penelitian pada koperasi di Kota Bogor dengan menggunakan analisis kuantitatif.

\section{METODE PENELITIAN}

Penelitian ini menggunakan metode survai penjelasan (explanatory survey method) dikemukakan Singarimbun \& Effendi (2003), bertujuan menguji hipotesis yang telah dirumuskan sebelumnya (testing research). Unit analisis dalam penelitian ini adalah pengurus dan anggota koperasi. Jenis data primer yang dibutuhkan dalam penelitian ini adalah berupa himpunan informasi yang diperoleh dengan metode wawancara dan menggunakan kuesioner terstruktur yang diberikan kepada pengurus dan anggota koperasi yang menjadi responden terpilih. Data sekunder didapat dengan menelaah data yang diperoleh dari bagian administrasi dan publikasi yang telah diterbitkan.

\section{Operasionalisasi Variabel}

Untuk menjawab permasalahan, variabel yang akan dianalisis dalam penelitian ini terdiri dari variabel bebas, yaitu intellectual capital $\left(\mathrm{X}_{1}\right)$, manajemen keanggotaan $\left(\mathrm{X}_{2}\right)$, partisipasi anggota $\left(\mathrm{X}_{3}\right)$. Variabel terikat yaitu keunggulan bersaing $(\mathrm{Y})$.

Oleh karena skala pengukuran dalam data yang dikumpulkan masih skala ordinal, maka sebelum dilakukan pengujian dengan path analysis perlu

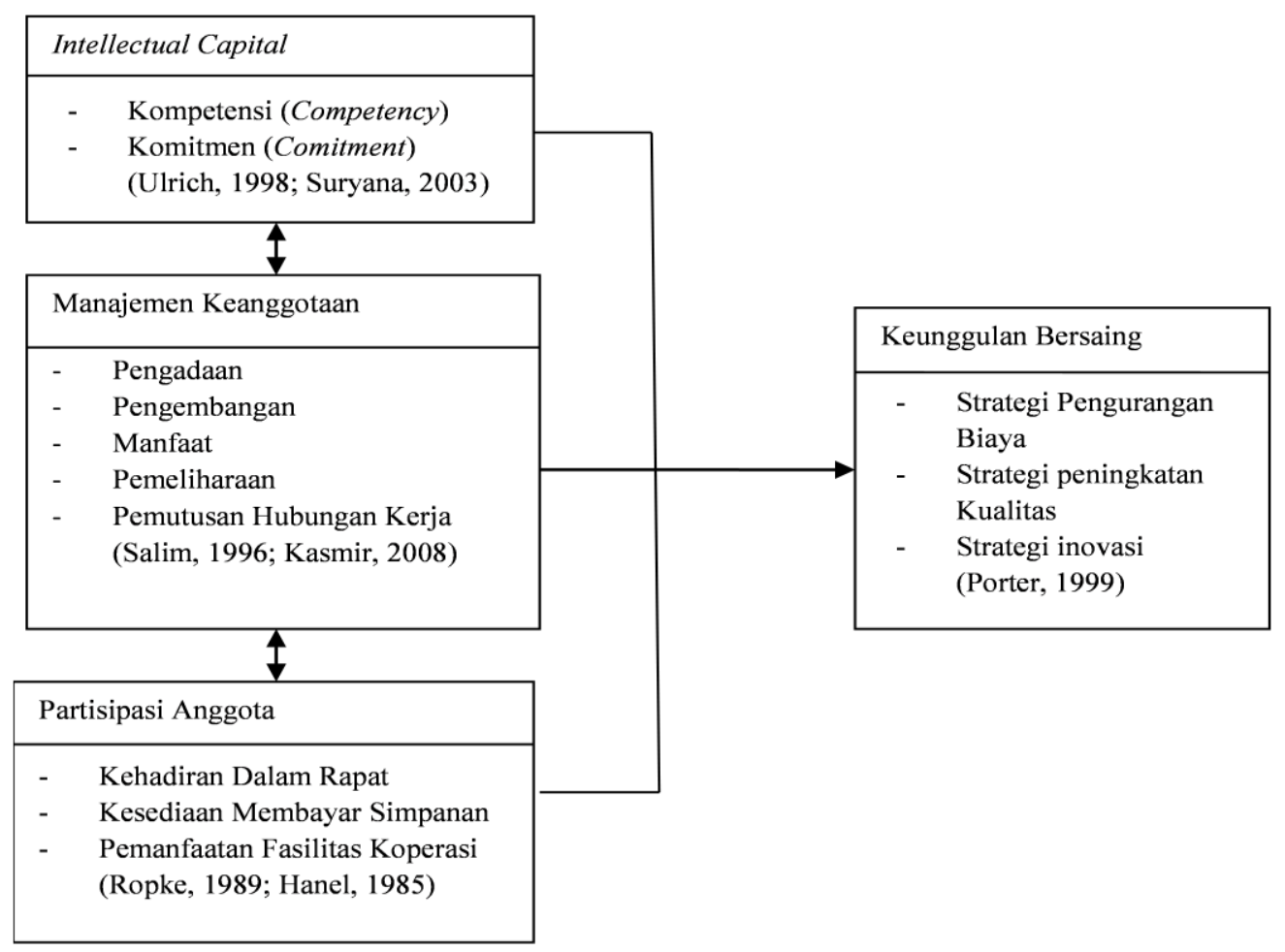

Gambar 1. Paradigma Penelitian 
terlebih dahulu menaikkan skala pengukuran dari ordinal ke skala interval. Untuk kenaikan pengukuran skala digunakan tingkat pengukuran interval (Method of Successive Interval). Menurut Sitepu (1994) dengan langkah kerja berikut ini: 1) Memperhatikan setiap item pertanyaan; 2) Untuk setiap item tersebut, hitung frekuensi jawaban (f), tentukan berapa responden yang mendapat skor $1,2,3,4,5 ; 3)$ Tentukan proporsi (p) dengan cara membagi frekuensi dengan jumlah responden; 4) Kemudian dihitung proporsi kumulatifnya (pk); 5) Hitung nilai Z untuk setiap proporsi kumulatif yang diperoleh dengan menggunakan tabel normal; 6) Tentukan nilai interval rata-rata (scale value) untuk setiap nilai $\mathrm{Z}$ dengan rumus sebagai berikut:

Scale Value $=$

(Kepadatan batas bawah) - (Kepadatan batas atas) (Daerah dibawah batas atas) -(Daerah dibawah batas bawah) (Hays, 1969).

7) Menentukan nilai transformasi (nilai untuk skala interval) dengan menggunakan rumus: Nilai Transformasi $=$ Nilai Skala $+\mid$ Nilai Skala Minimal $\mid+1$

Secara lebih rinci, operasionalisasi variabel tersebut dapat dilihat pada Tabel 2.

\section{Populasi Sasaran}

Sampel diambil dengan teknik two stage sampling (sampling dua tahap). Tahap pertama secara cluster sampling dipilih sejumlah koperasi secara acak berdasarkan wilayah. Yang selanjutnya pada tahap kedua secara stratified random sampling dipilih 33 koperasi secara acak menurut jenis koperasi, yaitu koperasi pegawai negeri Republik Indonesia (14 koperasi), koperasi karyawan (13 koperasi) dan koperasi lainnya (6 koperasi). Jumlah responden anggota koperasi ditentukan dengan teknik iterasi berdasarkan perkiraan nilai koefisien korelasi itemitem total dalam uji validitas item-item kuesioner (Sitepu, 1994). Rumus yang digunakan adalah berikut ini:

$$
\begin{aligned}
& n_{1}=\frac{\left(Z_{1-\alpha}+Z_{1-\beta}\right)^{2}}{\left(U^{1} p\right)^{2}}+3 \text { yang mana: } \\
& U^{\prime} p=1 / 2 \ln \left(\frac{1+P}{1-P}\right) \\
& n_{2}=\frac{\left(Z_{1-\alpha}+Z_{1-\beta}\right)^{2}}{(U p)^{2}}+3 \text { yang mana: } \\
& U p=1 / 2 \ln \left(\frac{1+P}{1-P}\right)+\left(\frac{P}{2\left(n_{1}-1\right)}\right)
\end{aligned}
$$

\begin{tabular}{|c|c|c|c|c|c|}
\hline \multirow{3}{*}{$\begin{array}{l}\text { Variabel } \\
\text { Intellectual } \\
\text { Capital }\left(\mathrm{X}_{1}\right)\end{array}$} & Sub Variabel & Konsep Variabel & Indikator & Ukuran & Skala Ukuran \\
\hline & $\begin{array}{l}\text { Kompetensi } \\
\left(\mathrm{X}_{1.1}\right)\end{array}$ & $\begin{array}{l}\text { Menyatakan kemampuan } \\
\text { seorang dalam } \\
\text { memanfaatkan atau } \\
\text { menggunakan ketrampilan } \\
\text { serta ilmu pengetahuan } \\
\text { yang ada padanya, } \\
\text { digunakan dalam } \\
\text { melaksanakan pekerjaan } \\
\text { yang menjadi tanggung } \\
\text { jawab. }\end{array}$ & $\begin{array}{l}\text { - Orientasi penetapan } \\
\text { standar kerja } \\
\text { - Upaya untuk } \\
\text { meningkatkan kualitas } \\
\text { - Profesionalisme dalam } \\
\text { menjalankan kegiatan } \\
\text { pelayanan jasa } \\
\text { - Mempunyai pengetahuan } \\
\text { dan ketrampilan tertentu } \\
\text { - Mempunyai rasa } \\
\text { tanggung jawab berkaitan } \\
\text { dengan profesionalisme }\end{array}$ & $\begin{array}{l}\text { Tingkat pelaksanaan } \\
\text { kompetensi yang } \\
\text { dilakukan pengurus } \\
\text { atau anggota } \\
\text { koperasi }\end{array}$ & $\begin{array}{l}\text { Interval } \\
\text { Interval } \\
\text { Interval } \\
\text { Interval }\end{array}$ \\
\hline & $\begin{array}{l}\text { Komitmen } \\
\left(\mathrm{X}_{1.2}\right)\end{array}$ & $\begin{array}{l}\text { Menyatakan tingkat } \\
\text { kepercayaan dan } \\
\text { penerimaan tenaga kerja } \\
\text { terhadap tujuan organisasi/ } \\
\text { koperasi dan mempunyai } \\
\text { keinginan untuk tetap ada } \\
\text { di dalam organisasi/ } \\
\text { koperasi tersebut. }\end{array}$ & 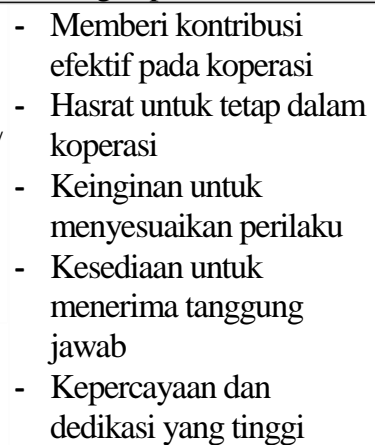 & $\begin{array}{l}\text { Tingkat pelaksanaan } \\
\text { komitmen yang } \\
\text { dilakukan pengurus } \\
\text { atau anggota } \\
\text { koperasi }\end{array}$ & $\begin{array}{l}\text { Interval } \\
\text { Interval } \\
\text { Interval }\end{array}$ \\
\hline
\end{tabular}

Tabel 2. Operasionalisasi Variabel 


\begin{tabular}{|c|c|c|c|c|c|}
\hline Variabel & Sub Variabel & Konsep Variabel & Indikator & Ukuran & Skala Ukuran \\
\hline \multirow[t]{5}{*}{$\begin{array}{l}\text { Manajemen } \\
\text { Keanggotaan } \\
\text { (X2) }\end{array}$} & $\begin{array}{l}\text { Pengadaan } \\
\left(\mathrm{X}_{2.1}\right)\end{array}$ & $\begin{array}{l}\text { Menyatakan } \\
\text { pengadaan anggota } \\
\text { sesuai dengan } \\
\text { kebutuhan jumlah, } \\
\text { kualitas dan jenis } \\
\text { usahanya }\end{array}$ & $\begin{array}{l}\text { - Sebelum menjadi } \\
\text { anggota dilakukan } \\
\text { penyuluhan tentang } \\
\text { koperasi } \\
\text { - Jumlah anggota } \\
\text { koperasi meningkat } \\
\text { setiap tahun } \\
\text { - } \\
\text { Koperasi selalu } \\
\text { memenuhi kebutuhan } \\
\text { anggotanya }\end{array}$ & $\begin{array}{l}\text { Tingkat } \\
\text { pelaksanaan } \\
\text { pengadaan yang } \\
\text { dilakukan koperasi }\end{array}$ & $\begin{array}{l}\text { Interval } \\
\text { Interval }\end{array}$ \\
\hline & $\begin{array}{l}\text { Pengembangan } \\
\left(\mathrm{X}_{2.2}\right)\end{array}$ & $\begin{array}{l}\text { Menyatakan suatu } \\
\text { kegiatan } \\
\text { meningkatkan mutu } \\
\text { usaha anggota agar } \\
\text { dapat mengikuti } \\
\text { perkembangan } \\
\text { koperasi }\end{array}$ & $\begin{array}{l}\text { - Selama menjadi } \\
\text { anggota selalu } \\
\text { mengikuti pelatihan } \\
\text { tentang perkoperasian } \\
\text { - Pelatihan berhubungan } \\
\text { dengan peningkatan } \\
\text { usaha koperasi } \\
\text { - Dapat mengelola } \\
\text { koperasi dengan baik }\end{array}$ & $\begin{array}{l}\text { Tingkat } \\
\text { pelaksanaan } \\
\text { pengembangan } \\
\text { yang dilakukan } \\
\text { koperasi }\end{array}$ & $\begin{array}{l}\text { Interval } \\
\text { Interval }\end{array}$ \\
\hline & Manfaat $\left(\mathrm{X}_{2.3}\right)$ & $\begin{array}{l}\text { Menyatakan bahwa } \\
\text { melaksanakan } \\
\text { pemberian balas jasa } \\
\text { yang layak bagi } \\
\text { anggota koperasi } \\
\text { sesuai dengan program } \\
\text { kerja }\end{array}$ & $\begin{array}{l}\text { - Dalam mengelola } \\
\text { koperasi diberikan } \\
\text { balas jasa dari koperasi } \\
\text { - } \text { Koperasi memberikan } \\
\text { potongan harga } \\
\text { - Anggota setiap tahun } \\
\text { diberikan SHU }\end{array}$ & $\begin{array}{l}\text { Tingkat } \\
\text { pelaksanaan } \\
\text { manfaat yang } \\
\text { dilakukan koperasi }\end{array}$ & $\begin{array}{l}\text { Interval } \\
\text { Interval }\end{array}$ \\
\hline & $\begin{array}{l}\text { Pemeliharaan } \\
\left(\mathrm{X}_{2.4}\right)\end{array}$ & $\begin{array}{l}\text { Menyatakan bahwa } \\
\text { fungsi } \\
\text { mempertahankan dan } \\
\text { meningkatkan } \\
\text { kesejahteraan para } \\
\text { anggota }\end{array}$ & $\begin{array}{l}\text { - } \text { Koperasi } \\
\text { memperhatikan } \\
\text { kesejahteraan } \\
\text { anggotanya } \\
\text { - Pemberian } \\
\text { kesejahteraan memadai } \\
\text { - Koperasi memberikan } \\
\text { bantuan pengobatan } \\
\text { pada anggotanya }\end{array}$ & $\begin{array}{l}\text { Tingkat } \\
\text { pelaksanaan } \\
\text { pemeliharaan yang } \\
\text { dilakukan koperasi }\end{array}$ & $\begin{array}{l}\text { Interval } \\
\text { Interval }\end{array}$ \\
\hline & $\begin{array}{l}\text { Pemutusan } \\
\text { Hubungan } \\
\text { Kerja }\left(\mathrm{X}_{2.5}\right)\end{array}$ & $\begin{array}{l}\text { Menyatakan bahwa } \\
\text { fungsi ini untuk } \\
\text { melaksanakan } \\
\text { pemutusan hubungan } \\
\text { keanggotaan sesuai } \\
\text { dengan peraturan yang } \\
\text { berlaku }\end{array}$ & $\begin{array}{l}\text { - Anggota koperasi } \\
\text { melanggar keputusan } \\
\text { sehingga dilakukan } \\
\text { PHK } \\
\text { - Sanksi PHK selalu } \\
\text { diterapkan secara baik }\end{array}$ & $\begin{array}{l}\text { Tingkat } \\
\text { pelaksanaan } \\
\text { pemutusan } \\
\text { hubungan } \\
\text { pekerjaan yang } \\
\text { dilakukan koperasi }\end{array}$ & Interval \\
\hline \multirow[t]{3}{*}{$\begin{array}{l}\text { Parsipasi } \\
\text { Anggota } \\
\text { (X3) }\end{array}$} & $\begin{array}{l}\text { Kehadiran } \\
\text { Rapat }\left(X_{3.1}\right)\end{array}$ & $\begin{array}{l}\text { Menyatakan } \\
\text { kontribusi anggota } \\
\text { dalam mengambil } \\
\text { keputusan }\end{array}$ & - RAT & $\begin{array}{l}\text { Tingkat partisipasi } \\
\text { anggota dalam } \\
\text { koperasi }\end{array}$ & Interval \\
\hline & $\begin{array}{l}\text { Kesediaan } \\
\text { Membayar } \\
\left(\mathrm{X}_{3.2}\right)\end{array}$ & & $\begin{array}{l}\text { - Kesediaan membayar } \\
\text { simpanan pokok, wajib } \\
\text { dan dana cadangan }\end{array}$ & & Interval \\
\hline & $\begin{array}{l}\text { Pemanfaatan } \\
\text { Pelayanan Unit } \\
\text { Usaha }\left(\mathrm{X}_{3.3}\right)\end{array}$ & & $\begin{array}{l}\text { - Kesesuaian antara } \\
\text { pelayanan usaha yang } \\
\text { ditawarkan koperasi } \\
\text { dengan keinginan } \\
\text { anggotanya mencakup } \\
\text { bidang penjualan, } \\
\text { produk, jasa simpan } \\
\text { pinjam }\end{array}$ & & Interval \\
\hline
\end{tabular}




\begin{tabular}{|c|c|c|c|c|c|}
\hline Variabel & Sub Variabel & Konsep Variabel & Indikator & Ukuran & Skala Ukuran \\
\hline $\begin{array}{l}\text { Keunggulan } \\
\text { Bersaing (Y) }\end{array}$ & $\begin{array}{l}\text { Strategi } \\
\text { pengurangan } \\
\text { biaya }\end{array}$ & $\begin{array}{l}\text { Menyatakan strategi } \\
\text { dalam keunggulan } \\
\text { bersaing }\end{array}$ & $\begin{array}{l}\text { - Pengendalian biaya ketat } \\
\text { - Membuat laporan } \\
\text { pengendalian biaya } \\
\text { secara kontinyu }\end{array}$ & $\begin{array}{l}\text { Tingkat keunggulan } \\
\text { bersaing dalam } \\
\text { koperasi }\end{array}$ & $\begin{array}{l}\text { Interval } \\
\text { Interval }\end{array}$ \\
\hline & $\begin{array}{l}\text { Strategi } \\
\text { peningkatan } \\
\text { kualitas }\end{array}$ & & $\begin{array}{l}\text { - Pengawasan ketat } \\
\text { terhadap pengurus } \\
\text { - Kemudahan mendapat } \\
\text { modal }\end{array}$ & & $\begin{array}{l}\text { Interval } \\
\text { Interval }\end{array}$ \\
\hline & Strategi inovasi & & $\begin{array}{l}\text { - Membuat rancangan } \\
\text { produk yang mudah } \\
\text { - } \text { Memberikan fasilitas } \\
\text { yang menarik bagi tenaga } \\
\text { kerja yang terampil }\end{array}$ & & $\begin{array}{l}\text { Interval } \\
\text { Interval }\end{array}$ \\
\hline
\end{tabular}

Untuk $\mathrm{n}_{1} \neq \mathrm{n}_{2}$ dilakukan iterasi berikutnya hingga diperoleh nilai yang sama. Rumus $n_{j}(j=3,4$, ...) sama dengan rumus untuk $\mathrm{n}_{2}$. Dengan perkiraan harga koefisien korelasi $(\mathrm{p})$ terkecil $=0,35$ (nilai estimasi di atas nilai tengah kategori keeratan hubungan lemah; 0,20-0,399 Sugiono, 2008), taraf nyata $(\alpha)=5 \%$ dan kuasi uji

$(1-\beta)=95 \%$ diperoleh ukuran sampel minimal sama dengan 84. Adanya penggunaan teknik cluster sampling pada tahap pertama penentuan sampel koperasi menyebabkan ukuran sampel minimal yang dipersyaratkan menjadi dua kali ukuran sampel minimal dari penggunaan rumus di atas, yaitu $2 \times 84$ $=168$ yang dibulatkan menjadi 208 responden.

\section{Metode Analisis dan Langkah-Langkahnya}

Data yang terkumpul akan dianalisis secara deskriptif dan verifikatif dengan menggunakan uji statistik. Untuk menguji hipotesis penelitian yang diajukan digunakan uji statistik (path analysis) dengan langkah sebagai berikut:

a. Menggambar diagram jalur proporsi hipotesis yang diajukan dan persamaan strukturalnya yaitu:

1) Diagram jalur hipotesis yang diajukan seperti pada Gambar 2.

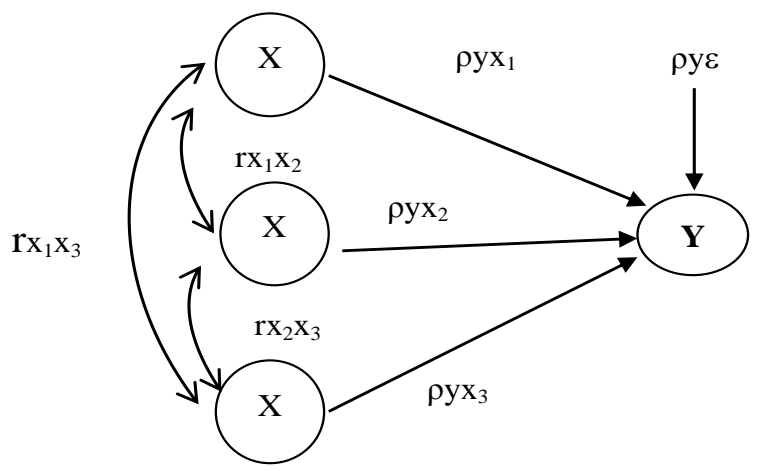

Gambar 2. Koefisien Jalur Variabel $X_{i}$ terhadap Variabel Y
Keterangan:

$\mathrm{X}_{1}=$ Intellectual Capital;

$\mathrm{X}_{2}=$ Manajemen Keanggotaan;

$\mathrm{X}_{3}=$ Partisipasi Anggota;

$\mathrm{Y}=$ Keunggulan Bersaing;

$\varepsilon=$ Error

2) Persamaan strukturalnya: $Y=P_{y x 1}, X_{1}+P_{y \times 2}$. $\mathrm{X}_{2}+\mathrm{P}_{\mathrm{yx} 3} . \mathrm{X}_{3}+\varepsilon$

Hubungan antara $X_{1}, X_{2}$ dan $X_{3}$ adalah hubungan korelasional intensitas keeratan hubungannya dinyatakan oleh besarnya koefisien korelasi $\mathrm{r}_{\mathrm{x} 1 \times 3}$. Hubungan $\mathrm{X}_{1}, \mathrm{X}_{2}$ dan $\mathrm{X}_{3}$ ke $\mathrm{Y}$ adalah hubungan kausal. Besarnya pengaruh langsung (relatif) dari $\mathrm{X}_{1} \mathrm{ke} \mathrm{Y}, \mathrm{X}_{2} \mathrm{ke}$ $\mathrm{Y}$, dan $\mathrm{X}_{3}$ ke $\mathrm{Y}$ masing-masing dinyatakan oleh besarnya nilai numerik koefisien jalur $\mathrm{P}_{\mathrm{YX} 1}, \mathrm{P}_{\mathrm{YX} 2}$ dan $\mathrm{P}_{\mathrm{YX} 3}$ koefisien jalur $\mathrm{P}_{\mathrm{Y} \varepsilon}$ menggambarkan besarnya pengaruh langsung (relatif) variabel residu $\varepsilon$ (implict exogeneous variabel) terhadap Y.

b. Pengujian hipotesis, karena data yang digunakan untuk menguji proposisi hipotetik yang dikemukakan dalam penelitian dasarnya adalah sampel berukuran n, maka sebelum menarik kesimpulan mengenai hubungan kausal digambarkan oleh diagram jalur diperlukan menguji kebermaknaan (test of significance). Menghitung pengaruh secara simultan dan parsial.

\section{HASIL PENELITIAN}

Koperasi yang dijadikan sampel berdasarkan lama usahanya 5-10 tahun dan jenis usaha koperasi Kota Bogor yaitu toko dan simpan pinjam. Deskripsi responden yang berjenis kelamin laki-laki sebanyak 166 orang dan perempuan 42 orang. Terbanyak lakilaki hal ini menunjukkan bahwa responden tersebut sebagai kepala keluarga yang bekerja. Responden 
yang berusia antara 25 - 35 tahun paling banyak yaitu 93 orang, disusul responden yang berusia lebih dari 35 tahun sebanyak 82 orang dan responden yang berusia kurang dari 25 tahun sebanyak 33 orang. Hal ini menunjukan bahwa usia terbanyak adalah usia produktif. Berdasarkan tingkat pendidikan tamatan SMA yaitu sebanyak 130 orang, Diploma sebanyak 26 orang, pendidikan S-1 sebanyak 37 orang dan Pendidikan S-2 sebanyak 15 orang. Hal ini menunjukkan bahwa koperasi memiliki anggota terbanyak berpendidikan SMA. Berdasarkan Jabatan bahwa Ketua Koperasi sebanyak 22 orang, Wakil Ketua Koperasi sebanyak 11 orang, Manajer sebanyak 15 orang, Sekretaris sebanyak 11 orang, Bendahara sebanyak 22 orang dan Anggota Koperasi sebanyak 127 orang. Hal ini menunjukan bahwa berdasarkan jabatan terbanyak anggota koperasi karena anggota koperasi mempunyai dua identitas yaitu anggota sebagai pemilik koperasi dan sebagai pelanggan koperasi serta dalam struktur organisasi koperasi Rapat Anggota Tahunan atau RAT tertinggi.

\section{Deskripsi Hasil Kuesioner}

Intellectual capital melalui komitmen dan kompetensi pengurus dan anggota koperasi dapat memberikan manfaat bagi koperasi serta bersamasama memajukan koperasi sehingga koperasi tersebut memperoleh keuntungan pada usaha dan manfaatnya. Bahwa komitmen pengurus dan anggota koperasi masih cenderung menyatakan cukup baik yaitu $58,17 \%$. Komitmen pengurus dan anggota koperasi dapat dipengaruhi dan dibentuk oleh budaya yang ada di dalam organisasi. Dua unsur pokok yang sangat menentukan keberhasilan suatu organisasi yang terdiri atas para individu yang memiliki bakat, visi, karakteristik serta nilai masing-masing, dalam mencapai tujuan-tujuan yang telah ditetapkan sebelumnya, yaitu kepercayaan dan komitmen. Bahwa hanya kredibilitas yang tinggi dan mampu menghasilkan suatu komitmen (pengurus dan anggota koperasi) yang tinggi akan bermanfaat setidaknya bagi tiga pihak; yaitu: (1) pekerjaan itu sendiri, yang melaksanakan pekerjaannya dengan senang hati, (2) pelanggan yang lebih puas dengan pelayanan yang diberikan dengan senang hati dan ketulusan; serta (3) koperasi itu sendiri yang akan menikmati peningkatan perolehan pendapat dan reputasi yang positif. Kompetensi pengurus dan anggota koperasi masih cenderung menyatakan cukup baik yaitu $75,60 \%$. Hal ini mengingat, bahwa para pengurus dan anggota koperasi yang memiliki keterampilan profesional dan kompentensi yang tinggi, mampu untuk tidak saja melakukan pengembangan secara terbatas pada lingkup koperasi, tetapi mampu pula, pada saat yang bersamaan melakukan identifikasi untuk pengembangan di masa yang akan datang agar mencapai keunggulan bersaing. Pengembangan perusahaan koperasi tidak harus membatasi diri hanya sebatas untuk memenuhi kebutuhan anggotanya sendiri, tetapi juga dapat memanfaatkan potensi ekonomi yang ada untuk kepentingan peningkatan kesejahteraan anggota dan masyarakat disekitarnya. Manajemen keanggotaan melalui pengadaan anggota koperasi selalu diusahakan agar jumlah anggota koperasi setiap tahun meningkat, sehingga memberikan keuntungan dan manfaat bagi koperasi itu sendiri yaitu $71,15 \%$ bahwa proses pengadaan yang ada pada koperasi cukup baik, disebabkan pengetahuan tentang berkoperasi dalam menjalankan fungsinya. Pengembangan selama menjadi anggota koperasi mengikuti pelatihan tentang perkoperasian yaitu $62,82 \%$ menyatakan cukup baik karena melalui pengembangan pengurus dan anggota koperasi maka koperasi dapat dikelola dengan baik. Manfaat merupakan salah satu fungsi yang penting dalam menjalankan usaha koperasi. Kegiatan koperasi ini memberikan balas jasa terhadap pengurus atau anggota bila berkoperasi sebesar 56,25\% menyatakan cukup baik manfaat yang diberikan karena koperasi melakukan usahanya belum banyak sehingga manfaat yang diperoleh dengan menjadi anggota koperasi masih terasa kurang. Pemeliharaan merupakan bagian sangat menentukan dalam kelangsungan koperasi, sehingga selaku pengurus selalu memperhatikan tingkat kesejahteraan para anggotanya agar anggota tetap menjadi anggota koperasi. Ada sebesar 67,31\% menyatakan baik dalam pemeliharaan, karena koperasi harus memelihara anggotanya agar anggota koperasi tetap mau menjadi anggotanya sehingga usaha koperasi dapat berkembang. Peran pemutusan hubungan kerja (PHK) pada koperasi mengakibatkan jumlah anggota koperasi berkurang sehingga aktivitas anggotanya dalam partisipasi dan kegiatan permodalan berkurang. Ada sebesar $58,42 \%$ menyatakan peran PHK kurang baik, hal ini berkaitan permodalan koperasi seandainya para anggota tidak terkendali didalam pengunduran diri sebagai anggota koperasi.

Partisipasi anggota koperasi sebesar 74,84\% menyatakan penting partisipasi anggota karena adanya anggota berpartisipasi sehingga koperasi akan mengalami kemajuan. Pengukuran keunggulan bersaing bagi koperasi sebesar $72,79 \%$ menyatakan cukup baik hal ini dikarenakan pengurus dan anggota koperasi harus berhasil dalam kegiatan usahanya, pengaman dana-dana yang berasal dari anggota, pelayanan yang diberikan dengan berpedoman pada manajemen koperasi. Keunggulan bersaing pada 
dasarnya tumbuh dari nilai atau manfaat yang dapat diciptakan koperasi bagi para pembelinya yang lebih dari biaya yang harus dikeluarkan koperasi untuk menciptakannya. Nilai atau manfaat inilah yang sedia dibayar oleh pembeli, dan nilai yang unggul berasal dari penawaran harga yang lebih rendah ketimbang harga pesaing untuk manfaat setara atau penawaran manfaat unik yang melebihi harga yang ditawarkan (Porter, 1999). Jika koperasi menjalankan bisnis, maka prinsip dasar untuk mencapai keuntungan adalah membeli dengan harga rendah dan menjualnya dengan harga sama dengan di pasar atau lebih rendah dari harga pasar, karena tujuan koperasi kesejahteraan anggotanya. Pada dasarnya setiap koperasi telah mempunyai suatu strategi. Hanya terkadang tidak menyadari bahwa rencana dari aktivitas yang sedang dijalankan oleh koperasi merupakan salah satu strategi. Ketidaktahuan ini disebabkan tidak diinformasikan dan tidak dibudayakannya strategistrategi tersebut oleh koperasi agar diketahui oleh semua anggota dan pengurus koperasi. Bentuk strategi dapat bervariasi dari satu koperasi ke koperasi lain sehingga setiap koperasi mempunyai strategi sendiri yang berbeda dengan para pesaing. Strategi tersebut dikenal dengan strategi generic. Untuk menjadikan anggota sebagai kekuatan ekonomi, maka perusahaan koperasi harus dikelola dengan cara yang lebih efisien, lebih produktif dan lebih berdaya saing, sehingga menjadi semakin unggul. Hanya dengan cara demikian koperasi dapat memperoleh dukungan dan kepercayaan dari anggotanya. Cara-cara mengikat pelanggan seperti dengan memberikan pelayanan yang baik, menghilangkan jam kerja untuk dapat memberikan pelayanan yang baik dan kapan saja dibutuhkan, perhatian yang penuh pada kepuasan pelanggan, menjalin komunikasi yang ramah dan santun kepada pelanggan, serta mengembangkan kreativitas dan inovasi bisnis dalam menciptakan produk-produk unggulan bagi pelanggan akan memberikan jaminan kepastian pasar (captive market) yang kuat bagi koperasi.

\section{Pengujian Hipotesis}

Adapun pengujian hipotesis seperti Gambar 3.

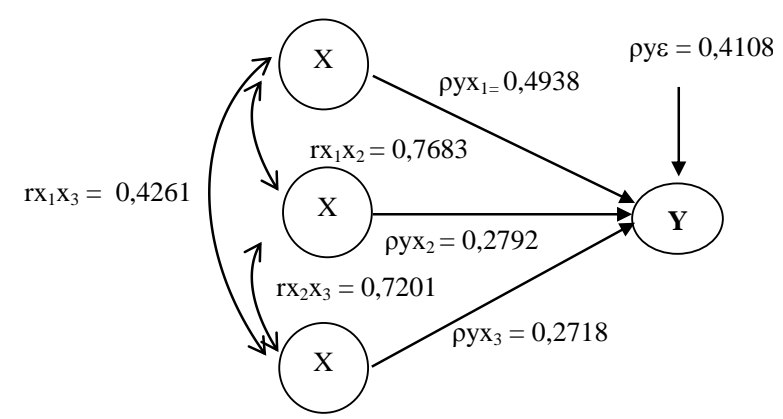

Gambar 3. Diagram Jalur
Persamaan strukturnya adalah:

$Y=0,4938 X_{1}+0,2792 X_{2}+0,2718 X_{3}+\varepsilon$.

Dari hasil perhitungan pengaruh variabel $X_{1}, X_{2}$ dan $\mathrm{X}_{3}$ terhadap $\mathrm{Y}$ melalui koefisien determinasi multiple sebesar $\mathrm{R}^{2}=0,8312$ sedangkan koefisien korelasi multiple melalui $\mathrm{R}=0,9117$. Uji $\operatorname{simultan} \mathrm{F}=$ 47,6151 > F tabel $=2,9340$ signifikan pada taraf kesalahan $5 \%$. Sedangkan uji secara parsial $t_{\mathrm{Yx} 1}=$ $3,9698>\mathrm{t}$ tabel $=1,6991 ; \mathrm{t}_{\mathrm{Yx} 2}=1,7216>\mathrm{t}$ tabel $=1$, $6991 ; \mathrm{t}_{\mathrm{Y} \times 3}=2,3687>$ tabel $=1,6991$ signifikan pada taraf kesalahan 5\%. Kesimpulannya bahwa $\mathrm{X}_{1}, \mathrm{X}_{2}$ dan $X_{3}$ secara simultan dan parsial berpengaruh terhadap Y.

\section{Interpretasi Pengaruh Intellectual Capital ter- hadap Keunggulan Bersaing}

Pengaruh total intellectual capital terhadap keunggulan bersaing sebesar 45,28\%, sedangkan pengaruh langsung intellectual capital terhadap keunggulan bersaing sebesar 24,38\%. Pengaruh tidak langsung intellectual capital terhadap keunggulan bersaing sebesar 10,59\% dan 10,31\%. Berdasarkan hasil yang nilai kuantitasnya, kondisi sedemikian ini, hanya dapat terjadi pada sumber daya manusia yang memiliki komitmen pada perusahaannya (Lapierre, 2000). Sementara itu studi yang dilakukan oleh Caruana \& Pitt (1997) berhasil membuktikan, bahwa rendahnya komitmen karyawan akan berakibat buruk bagi organisasi, antara lain dengan semakin memburuknya kinerja sebagai akibat dari semakin rendahnya kualitas pelayanan serta tingginya biaya yang harus dikeluarkan oleh perusahaan (Caruana, 1998). Sebagaimana pendapat Hamel dalam Horton (2000), yang menyatakan bahwa perkembangan kompentisi dewasa ini lebih merupakan kompetisi antar kompentensi dari masing-masing perusahaan. Faktor kemenangan terletak pada seberapa baik suatu organisasi melakukan pengelolaan kompentensi yang ada di perusahaannya dan dengan baik mengarahkan kepada suatu bentuk "distinctive" tertentu yang tidak mudah ditiru; dan kesemuanya terpulang kepada kemampuan manajemen dalam menegarai dan mengakusisi keterampilan-keterampilan yang relevan dan dibutuhkan oleh industrinya masing-masing. Teruji secara analisis statistik melalui uji $\mathrm{t}$ (parsial) bahwa intellectual capital berpengaruh terhadap keunggulan bersaing.

\section{Interpretasi Pengaruh Manajemen Keanggotaan dengan Keunggulan Bersaing}

Pengaruh total manajemen keanggotaan terhadap keunggulan bersaing sebesar $23,84 \%$, sedang- 
kan pengaruh langsung manajemen keanggotaan terhadap keunggulan bersaing sebesar 7,79\%. Pengaruh tidak langsung manajemen keanggotaan terhadap keunggulan bersaing sebesar 10,59\% dan $5,46 \%$. Berdasarkan hasil yang nilai kuantitasnya. Untuk itu yang mempengaruhi manajemen keanggotaan terhadap keunggulan bersaing yaitu: 1) Pendidikan adalah kunci pembuka modernisasi; 2) Pengalaman, kemampuan pengurus memiliki pengalaman dalam mengelola koperasi; 3) Kepemimpinan, seorang pengurus koperasi selain merupakan pimpinan organisasi juga sekaligus merupakan pimpinan bisnis. Dari sudut pandang teori manajemen keanggotaan merupakan suatu cara koperasi untuk mendapatkan anggota terus menerus. Jumlah anggota koperasi yang membesar akan mempengaruhi besarnya keunggulan bersaing koperasi. Oleh karena itu, pelaksanaan manajemen keanggotaan secara teori berhubungan dengan keunggulan bersaing. Fungsi manajemen keanggotaan koperasi melalui partisipasi anggota serta berusaha untuk memberikan saran-saran dan nasehat pada pengurus dan badan pengawas agar koperasi dapat berhasil dengan baik. Analisis statistik uji t (parsial) bahwa manajemen keanggotaan berpengaruh terhadap keunggulan bersaing.

\section{Interpretasi Pengaruh Partisipasi Anggota ter- hadap Keunggulan Bersaing}

Pengaruh total partisipasi anggota terhadap keunggulan bersaing sebesar $18,57 \%$, sedangkan pengaruh langsung partisipasi anggota terhadap keunggulan bersaing sebesar 7,39\%. Pengaruh tidak langsung partisipasi anggota terhadap keunggulan bersaing sebesar $5,72 \%$ dan 5,46\%. Berdasarkan hasil yang nilai kuantitasnya bahwa pendirian koperasi ditujukan untuk memenuhi kebutuhan anggota, artinya perusahaan koperasi sejatinya mampu memenuhi kebutuhan anggotanya. Demikian pula sebaliknya anggota memanfaatkan layanan koperasi, perhatian dan bertanggung jawab terhadap koperasi dalam bentuk kontribusi berbagai bentuk simpanan maupun ikut menanggung risiko usaha koperasi, serta secara proaktif ikut serta dalam berbagai bentuk maupun proses pengambilan keputusan usaha koperasi. Partisipasi anggota dilandaskan pada prinsip identitas gandanya (dual identity), yaitu anggota sebagai pemilik anggota wajib berpartisipasi dalam penyertaan modal, pengawasan dan membuat keputusan, sekaligus sebagai pengguna atau pelanggan, anggota koperasi wajib memanfaatkan fasilitas, layanan, barang, maupun jasa yang disediakan oleh koperasi. Derajat ketergantungan antara anggota dengan perusahaan koperasi atau sebaliknya akan menentukan baik buruknya perkembangan organisasi maupun usaha koperasi. Semakin kuat ketergantungan anggota dengan koperasi, maka semakin tinggi dan baik perkembangan organisasi dan usaha koperasi, sehingga koperasi merasakan manfaat keberadaan koperasi dan koperasi semakin sehat berkembang sebagai badan usaha atas dukungan anggota secara penuh. Koperasi memberikan manfaat (cooperative effect) secara ekonomi langsung maupun tidak langsung bagi anggota, dan anggota mendukung, berinteraksi, dan proaktif bagi perkembangan usaha koperasi. Partisipasi anggota dengan koperasi seringkali juga terjadi konflik atau biasanya terjadi ketimpangan karena perbedaan kepentingan atau adanya konflik kepentingan antara anggota dengan koperasi. Perbedaan kepentingan ini dilatarbelakangi juga oleh homogenitas kepentingan anggota dengan perusahaan koperasi akan semakin harmonis hubungan keorganisasian maupun keusahaan koperasi, sehingga partisipasi anggota juga semakin tinggi. Beberapa kepentingan yang berkait dengan hal ini menyangkut tingkat pelayanan, kepentingan organisasi, serta penentuan dan pembagian sisa hasil usaha. Koperasi sebagai perusahaan harus mampu memenuhi kebutuhan anggota dengan berbagai variasinya maupun keterpencaran jarak anggota dalam proses pelayanan atas kebutuhan anggota. Koperasi diharuskan meningkatkan pelayanan kepada anggota-anggotanya, mengingat secara teori partisipasi anggota terhadap koperasi peranannya sama dengan keunggulan bersaing koperasi yang bersangkutan. Hal ini teruji menggunakan analisis statistik uji $\mathrm{t}$ (parsial) bahwa partisipasi anggota berpengaruh terhadap keunggulan bersaing.

\section{Interpretasi Pengaruh Penerapan Intellectual Capital dan Pelaksanaan Manajemen Keanggota- an Serta Semakin Aktif Partisipasi Anggota Terhadap Keunggulan Bersaing}

Pengaruh secara bersama-sama (simultan) dari ketiga variabel ini (intellectual capital, manajemen keanggotaan, partisipasi anggota) terhadap keunggulan bersaing perlu diungkapkan untuk memperoleh hasil penelitian komperhensif. Pembuktian dengan menggunakan uji $\mathrm{F}$ antara intellectual capital, manajemen keanggotaan dan partisipasi anggota mempunyai pengaruh terhadap keunggulan bersaing. Indikasinya adalah semakin baik penerapan intellectual capital dan semakin tepat pelaksanaan manajemen keanggotaan serta semakin aktif partisipasi anggota maka semakin baik pula keunggulan bersaing koperasi tersebut. Dengan demikian pendekatan statistik dapat dibuktikan bahwa secara 
bersama intellectual capital dan manajemen keanggotaan serta partisipasi anggota berpengaruh terhadap keunggulan bersaing ditunjukkan oleh nilai koefisien determinasi sebesar $83,12 \%$, sisanya $16,88 \%$ disebabkan faktor lain sedangkan korelasinya sebesar 0,9117. Dari uraian secara teori maupun fakta empiris melalui analisis data secara deskriptif dan statistik telah ditunjukkan mengukur pengaruh intellectual capital, manajemen keanggotaan dan partisipasi anggota terhadap keunggulan bersaing koperasi tercapai.

\section{SIMPULAN DAN SARAN}

Berdasarkan hasil penelitian yang telah diuraikan sebelumnya, maka dapat disimpulkan hal-hal sebagai berikut: 1) Penerapan intellectual capital melalui komitmen dan kompetensi berpengaruh terhadap keunggulan bersaing koperasi; 2) Tepatnya pelaksanaan manajemen keanggotaan melalui pengaturan pengadaan anggota, pengembangan jumlah anggota, pemberian manfaat koperasi, pemeliharaan anggota dan pemutusan hubungan keanggotaan berpengaruh terhadap keunggulan bersaing koperasi; 3) Aktifnya partisipasi anggota melalui partisipasi dalam rapat anggota, kesediaan membayar simpanan dan pemanfaatan fasilitas koperasi terhadap keunggulan bersaing koperasi; 4) Terdapat pengaruh antara intellectual capital dan manajemen keanggotaan serta partisipasi anggota terhadap keunggulan bersaing. Hal ini berarti semakin baik penerapan intellectual capital dan pelaksanaan manajemen keanggotaan serta aktifnya partisipasi anggota maka koperasi dapat mencapai keunggulan bersaing. Dari analisis kuantitatif dengan menggunakan koefisien determinasi diperoleh pengaruh intellectual capital dan manajemen keanggotaan serta partisipasi anggota terhadap keunggulan bersaing koperasi sebesar 83,12\% sedangkan 16,88\% disebabkan faktor lain.

Berdasarkan hasil penelitian, pembahasan dan simpulan, maka ada beberapa saran: 1) Temuan penelitian diperoleh bahwa intellectual capital dan manajemen keanggotaan serta partisipasi dalam keunggulan bersaing koperasi. Oleh sebab itu, disarankan agar pengurus sebagai anggota koperasi dan anggota koperasi memahami benar hal ini, sehingga koperasi sebagai salah satu wadah ekonomi agar dapat berperan dalam keunggulan bersaing koperasi melalui pegembangan ekonomi masyarakat pada umumnya dan bagi anggota pada khususnya; 2) Mengingat koperasi sangat potensial dilihat dari segi jumlah koperasi, jumlah anggota, permodalan, volume usaha dan sisa hasil usaha yang dihasilkan hendaknya dapat diberdayakan lembaga ini untuk menggerakkan roda perekonomian; 3) Fungsi koordinasi dan kerjasama antara koperasi perlu diupayakan agar koperasi di daerah ini dapat menjadi salah satu wadah ekonomi yang mampu membantu masyarakat dan dapat menunjang keunggulan bersaing melalui pengembangan usaha sekaligus dapat memberikan pelayanan yang lebih berpihak kepada masyarakat.

\section{DAFTAR REFERENSI}

Arikunto, S. 2009. Prosedur Penelitian, Suatu Pendekatan Praktis, Edisi Revisi. Jakarta: PT. Bina Aksara.

Azwar, S. 1997. Reliabilitas dan Validitas. Edisi Ke 3. Yogyakarta: Pustaka Pelajar.

Caruana, A. 1997. Market Orientation and Organizational Commitment in The Australian Public Sector, International Journal of Public Sector Management, 10(4): 294-303.

1998, The Effect of Internal Marketing on Organisational Commitment Among Retail Bank Managers, International Journal of Bank Maketing, 16(3): 108-116.

Caruana, A. \& Pitt, L. 1997, INTQUAL an Internal Measure of Service Quality and The Link Between Service Quality and Business Performance, European Journal of Marketing, 31(8): 604-616.

Davis, P. 1999. Managing The Cooperative Difference: A Survey of The Application of Modern Management Practices in The Cooperative Context. Geneva: International Labour Office.

Desatnick, R. L. 1988. Managing to Keep The Customers: How to Achieve and Maintain Superior Customer Service Throughout The Organization, San Fransisco: Jossey-Bass Publishers.

Dinas Koperasi dan UKM Kota Bogor, 2012. Keragaan Koperasi Kota Bogor Tahun 2011. Bogor: Dinas Koperasi dan UKM Kota Bogor.

Gilbert, G. R. 2000. Measuring Internal Customer Satisfaction, Managing Service Quality, 10(3): 178-186.

Gilbert, G. R. \& Parhizgari, A. M.. 2000. Organizational Effectiveness Indicators to Support Service Quality, 10(1): 46-51.

Hanel, A. 1985. Basic Aspect of Cooperative Organization and Policies for Their Promotion in Developing Countries Marburg. Germany: Marburg Consult für Selbsthilfeförderung . 1989. Organisasi Koperasi, Pokok-Pokok Pikiran Mengenai Organisasi Koperasi dan Kebijaksanaan Pengembangan di NegaraNegara Berkembang. Edisi Pertama. Bandung: Universitas Padjadjaran. 
Horton, S. 2000. Introduction-The Competency Movement: Its Origins and Impact on The Public Sector, The International Journal of Public Sector Management, 13(4): 306-318.

Kasmir, 2008. Manajemen Perbankan. Jakarta: PT. Raja Grafindo Persada.

Lapierre, J. 2000. Customer-Perceived Value in Industrial Contexts, Journal of Business and Industrial Marketing, 15(2): 122-140.

Porter, E. M. 1999. Strategi Bersaing; Teknik Menganalisis industri Dan Pesaing. Jakarta: Erlangga.

2011. Keunggulan Bersaing. Menciptakan dan Mempertahankan Kinerja Keunggulan. Jakarta: Bina Aksara.

Ropke, J. 1989. Teori Ekonomi Koperasi. Bandung: Program Pascasarjana Unpad.

2012. Ekonomi Koperasi Teori dan Manajemen, Jakarta, Salemba Empat.

Salim, S. 1996. Kebijakan Pembangunan dan Promosi Koperasi dalam Orasi Kuliah Program Pascasarjana. Bandung. Unpad.

Sekretariat Negara Republik Indonesia, UndangUndang Republik Indonesia No. 25 Tahun 1992 Tentang Perkoperasian. Bandung: Gunung Ilmu Press.

Singarimbun, M. \& Effendi, S. 2003. Metode Penelitian Survey Indonesia, Jakarta: PT. Pustaka LP3ES.
Sitepu, Nirwana S. K. 1994.Analisis Jalur (Path Analysis) Unit Pelayanan Statistika Jurusan Statistika MIPA. Bandung: Unpad.

Stewart, T. A. 1994. Intellectual Capital: The New Wealth of Organizations, New York: Doubleday.

Sugiono. 2008. Metode Penelitian Bisnis: Bandung. Alfabeta.

Suryana. 2003. Kewirausahaan Pedoman Praktis, Kiat dan Proses Menuju Sukses. Jakarta: Salemba Empat.

Swastha, B. D. H. 1999. Azas-Azas Marketing. Yogyakarta: Liberty.

Ulrich, D. 1998. Delivering Results, A New Mandate for Human Resource Professionals; Boston: Harvard Business School Press.

. 1998. Intellectual Capital $=$ Competence $x$ Commitmen. Sloan Management Review: Winter.

Usmara, A. 2002. Paradigma Baru Manajemen Sumber Daya Manusia. Jakarta: PT. Gramedia Pustaka Utama.

Wirasasmita, Y. 1992. Strategi Pembangunan Sektor Koperasi yang Dapat Menggerakkan Partisipasi Masyarakat dalam Pembangunan Koperasi. Dalam Rusidi dan Maman Suratman (Eds), Pokok-Pokok Pikiran tentang Pembangunan Koperasi. Bandung: UPT Penelitian. 